\title{
PROFITABILITY OF BALADI CALF FEEDLOTS UNDER DIFFERENT FATTENING SYSTEMS
}

Amal K. El- Asheeri

Department of Animal Production, Faculty of Agriculture, Cairo University, Giza, Egypt

\section{SUMMARY}

Forty Baladi male calves with body weight of $225-275 \mathrm{~kg}$ were used to study the growth traits and profitability of two fattening systems through two experiments. The aim of the $I^{\text {st }}$ was to study the effect of initial body weight $(B W)$ on feedlot profitability, while the aim of the $2^{\text {nd }}$ was to study the effect of final BW on the same traits of the $1^{\text {st }}$ experiment. Calves were divided into two groups $(G)$ based on their initial BW. G1 $(n=18)$ had BW of $240.7 \pm 1.7 \mathrm{~kg}$, which was lighter $(P<0.0001)$ than $G 2(G 2, n=22 ; 260.5 \pm 1.5 \mathrm{~kg})$ In both groups calves were fed to a final weight of $400 \mathrm{~kg}$ and those did not reach this weight were allowed to grow for a maximum fattening period of 6 months in $G 1$ and 5 months for G2. Growth traits were measured in terms of average daily gain (ADG) and fattening period, while benefit/cost ratio and net return (\%) were calculated as economic ones. After the end of experiment 1, 18 calves were chosen randomly to grow up to $415-425 \mathrm{~kg}$ (C2) to be compared with the profitability of feedlot that marketing their calves at $400 \mathrm{~kg}$ (C1). Calves were fed based on their body weight on concentrate feed mixture, rice straw and green maize fodder, while kept tied under shed on a semi-open yard. Animals were weighed once monthly during the experimental period to monitor the changes in $B W$ throughout the fattening period.

In the first experiment of studying the effect of initial $B W$ the overall means of final $B W$ and $A D G$ were $391.6 \pm 2.7$ and $0.90 \pm 0.02 \mathrm{~kg}$, respectively with no difference between $G 1$ and G2. This however, fattening period was shorter $(P<0.0001)$ in $G 2$ by about 17 days. Overall means of gross margin, benefit / cost ratio and net return/head/cycle were L.E $525.3 \pm 26.1,1.11 \pm 0.008$ and, $10.7 \pm$ $0.008 \%$ respectively with no significant difference between $G 1$ and $G 2$.

Results of the second experiment indicated that increase of marketing $B W$ over $400 \mathrm{~kg}$ had negative effect on growth traits and feedlot profitability. ADG of C2 was less $(P<0.0001)$ than $C 1$ by $16 \%$ with an average of $0.780 \pm 0.03$ and $0.929 \pm 0.03$ $\mathrm{kg}$, respectively. Benefit / cost ratio, net return (\%) per fattening cycle and annual net profit (\%) were $1.11 \pm 0.01$ vs. $1.05 \pm 0.01(P<0.005), 10.7 \pm 1.3$ vs. $4.95 \%(P<$ $0.004)$ and $26.5 \pm 2.8 v$ s. $9.6 \pm 3.1 \%$, respectively.

In conclusion, initial body weight (between 225 and $275 \mathrm{~kg}$ ) had no effect neither on growth traits nor feedlot profitability. Increasing marketing body over $400 \mathrm{~kg}$ decreases growth traits and feedlot profitability as well.

Keywords: Baladi cattle, growth, gain, body weight, fattening

INTRODUCTION

Beef industry depends mainly on availability of specialized genotypes in addition to natural rangelands which is not the case in Egypt. Beef production system in Egypt

Issued by The Egyptian Society of Animal Production 
depends mainly on fattening bovine Baladi, exotic breeds and buffalo male calves on concentrate feed mixture (feedlot) in two batches annually. This system is based on purchasing male calves with initial body weight of $200-250 \mathrm{~kg}$ to be fattened for six months aiming at reaching marketing weight of $400-450 \mathrm{Kg}$. Under these circumstances about $40 \%$ of the national demand of beef meat is produced (Ministry of Agriculture and Land Reclamation, 2006).

Growth pattern is influenced by genotype (Morsy et al., 1984), age (Sadek et al., 1993), sex (Lawrence and Fowler, 1998), season of the year (Omar et al., 1993) and type and level of feeding (El-Bedawy et al., 2004). On the other hand, feedlot profitability is the output of average daily gain (Omar et al., 1993), economic return (Alsheikh et al., 2004) and feed conversion (Nigm et al., 1984). Limited investigations were conducted to evaluate the economic efficiency of feedlot system in Egypt, which is characterized by highly invested capitals and gain net return of $12 \%$ per fattening cycle (Alsheikh et al., 2004).

Many studies were executed to describe growth aspects of Baladi calves throughout the fattening period either at experimental (Morsy et al., 1984 and Sadek et al., 1993); or commercial (Ashour et al., 2000, Omar et al., 1993 and Alsheikh et al., 2004) farm levels. The results of the previous studies showed a wide variation in average daily gain (600 - $1228 \mathrm{~g}$ /day) as reported by Askar and Ragab (1958); Kamar et al. (1961); Galal et al .(1973); Omar et al. (1993); El-Bedawy et al. (1996), Sadek et al. (1993), Alsheikh et al. (2004) and El-Bedawy et al. (2004).

The great increase in the international price of yellow corn represents a real challenge for beef producers in Egypt. Thus, beef producers have to reform their producing systems towards increasing feedlot profitability.

Testing different systems of fattening Baladi calves on feedlot profitability through reforming fattening period or marketing body weight was the aim of this study.

\section{MATERIALS AND METHODS}

The present study includes two experiments and carried out in the Experimental Farm Station, Faculty of Agriculture, Cairo University, Giza during year 2006.

\section{Experiment I}

\section{Animals and management}

The aim of this experiment was to shorten fattening period by testing two different initial body weights (IBW) on the net return of feedlot. A total number of 40 Baladi male calves between 225 and $275 \mathrm{~kg}$ were purchased from the local market based on their phenotype, health feature and body confirmation to study the growth performance and feedlot profitability under two IBWs simulating the systems applied in commercial feedlots. Animals were purchased during June and upon receiving, they were treated against the internal and external parasites in addition to vaccination against endemic diseases. Calves were fed to a final weight of $400 \mathrm{~kg}$ according to NRC (1996) requirements on concentrate feed mixture, green maize fodder $(15 \mathrm{~kg} /$ head/ day) and rice straw. Calves were kept tied under shed on semi-open yards during the experimental period. Calves were fed individually and watered thrice daily between 08:00 and 17:00 hr. 
According to the initial BW, calves were divided into two groups; the $1^{\text {st }}$ group $(\mathrm{G} 1=18)$ had BW between 225 and 249 with an average of $240.7 \pm 1.7 \mathrm{~kg}$, while the $2^{\text {nd }}$ group $(\mathrm{G} 2=22)$ was heavier $(\mathrm{P}<0.0001)$ having $\mathrm{BW}$ between 250 and 275 and an average of $260.5 \pm 1.5 \mathrm{~kg}$. Animals were fed to reach $400 \mathrm{~kg}$ as final body weight, and those that did not reach the target BW were allowed to grow for 6 months in G1 and 5 months of G2. Calves were weighed monthly after $18 \mathrm{hrs}$ fasting period. Growth (growth curve, ADG and fattening period) and economical traits (gross margin and benefit / cost ratio) per calf were calculated.

\section{Experiment II:}

After the end of the experiment $I$, the same calves $(n=40)$ were used in the $2^{\text {nd }}$ experiment. Eighteen calves (C2) were chosen randomly to grow up to $415-425 \mathrm{~kg}$ to study the impact of marketing body weight on growth and economic traits compared with those with $400 \mathrm{~kg}$ body weight of $(\mathrm{C} 1, \mathrm{n}=22)$.

\section{Economic measurements}

Fixed costs (administration, building and depreciation) were not considered assuming they are equal between the two systems of study. The economic analysis is based either on the invested capitals or running cost.

\section{Technical coefficients}

The prices in this study were based on the average prices of $2006-2007$
1. Concentrate feed mixture
$=$ L.E $1450 /$ ton
2. Green maize fodder
$=$ L.E $60 /$ ton
3. Rice straw
$=$ L.E $109 /$ ton
4. Veterinary care cost
$=$ L.E $50 /$ head $/$ year
5. Labor
$=$ L.E $20 / 50$ heads $/$ day
6. Purchasing price for $1 \mathrm{~kg}$ live weight $=\mathrm{L} . \mathrm{E} 14.5$
7. Selling price for $1 \mathrm{~kg}$ live weight $=\mathrm{L} . \mathrm{E} 13.75$
8. Produced manure $/$ calf $/$ year $=10 \mathrm{~m}^{3}$
9. Price of manure
= L.E $15 / \mathrm{m}^{3}$
10. Running cost
$=$ Feeding + veterinary care + labor
11. Total variable cost (LE)
$=$ Running cost + purchasing price

\section{Experimental measurements}

The following measurements were estimated as:
1. Average daily gain (ADG) weight divided by 30.5
2. Gross margin (L.E)
3. Benefit / cost ratio
4. Net return (\%)
$=$ Difference between two successive
$=$ Total income - total variable cost
$=$ Total income divided by total costs
$=$ Gross margin divided by total costs multiplied by 100

\section{Statistical analysis}

Data were analyzed using the General Linear Model (GLM) procedure (SAS, 2001). Differences between means were assessed by $t$ test. Data in percentages were transformed to the arcsine square-root to normalize errors before analysis. Model used was as follows:

$\mathrm{Y}_{\mathrm{ij}}=\mu+\mathrm{G}_{\mathrm{i}}+\mathrm{e}_{\mathrm{ij}}$, where,

$\mathrm{Y}_{\mathrm{ij}}=$ observation 
$\mu=$ mean

$\mathrm{G}_{\mathrm{i}}=$ the effect of initial body weight, $\mathrm{i}=1,2$

$\mathrm{G} 1=$ group with initial body weight of $225-250 \mathrm{~kg}$;

G2 = group with initial body weight of $250-275 \mathrm{~kg}$.

$\mathrm{e}_{\mathrm{ij}}=$ the experimental error

The same model was used to analyze the second experiment replacing $\mathrm{C}$ instead of $\mathrm{G}$ :

$\mathrm{C}_{\mathrm{i}}=$ the effect of marketing body weight, $\mathrm{i}=1,2$

$\mathrm{C} 1=$ group had marketing body weight of $390-400 \mathrm{~kg}$;

$\mathrm{C} 2=$ group had marketing body weight of $415-425 \mathrm{~kg}$.

\section{RESULTS}

\section{Experiment I}

1. Growth performance

Growth curve of Baladi calves under the present experimental conditions could be divided into three phases. The $1^{\text {st }}$ extended for one month during which the growth curve had a semi concave shape. This shape had transformed to be linear during the $2^{\text {nd }}$ phase and continued up to the $5^{\text {th }}$ month, before having a semi convex shape during the $3^{\text {rd }}$ phase (Figure 1).

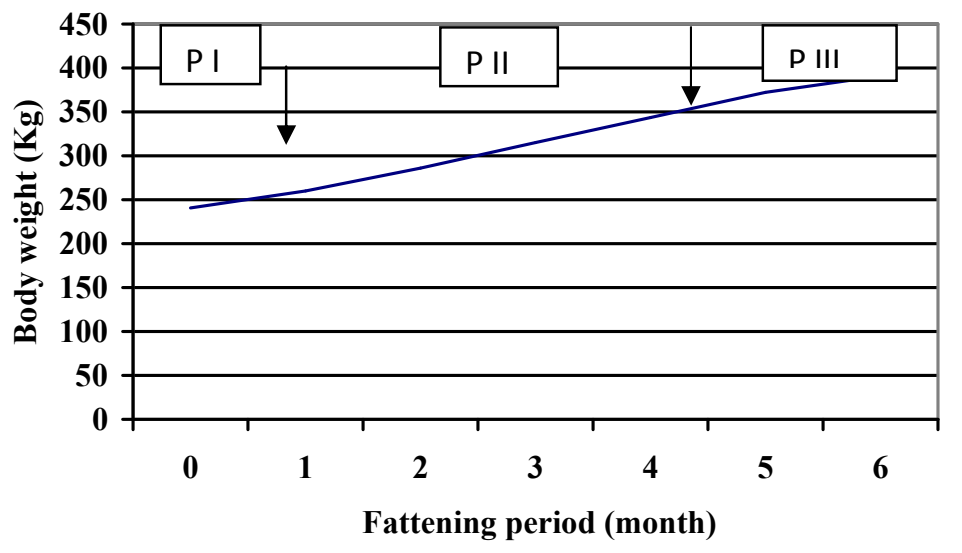
ADG
0.59
0.85
0.96
0.93
$0.94 \quad 0.84$
$(\mathrm{kg})$
$\pm 0.06 \pm 0.05$
$\pm 0.04 \quad \pm 0.04 \quad \pm 0.03$
$\pm 0.06$

Figure 1. Growth curve and ADG (kg) of Baladi calves throughout the growth phases of the experimental period

ADG was $0.59 \pm 0.06 \mathrm{~kg}$ during the $1^{\text {st }}$ months of fattening period reached its peak $(0.96 \pm 0.04 \mathrm{~kg})$ by the $3^{\text {rd }}$ month. ADG sustained around that value up to the $5^{\text {th }}$ months before decreasing to $0.84 \pm 0.06 \mathrm{~kg}$ during the $3^{\text {rd }}$ phase (Figure 1). The overall mean of ADG was $0.90 \pm 0.02 \mathrm{~kg}$ (Table 1 ).

By the end of the experiment calves reached $391.6 \pm 2.7 \mathrm{~kg}$ through fattening period of $156.7 \pm 2.4$ day. The gained weight (about $140 \mathrm{~kg}$ ) during the experimental period represents $57.6 \%$ of the initial BW. 
Table 1. Growth characteristics (LSM \pm S.E) of Baladi calves as affected by initial body weight (Experiment I)

\begin{tabular}{lcccc}
\hline Trait & G1 & G2 & $\begin{array}{c}\text { Overall } \\
\text { mean }\end{array}$ & P value \\
\hline Number & 18 & 22 & 40 \\
Initial body weight $(\mathrm{kg})$ & $240.7 \pm 1.7$ & $260.5 \pm 1.5$ & $251.7 \pm 1.1$ & 0.0001 \\
Final body weight $(\mathrm{kg})$ & $392.3 \pm 3.0$ & $390.9 \pm 2.7$ & $391.6 \pm 2.0$ & 0.727 \\
Fattening period (day) & $171.3 \pm 3.9$ & $144.9 \pm 3.3$ & $156.7 \pm 2.4$ & 0.0001 \\
Average daily gain $(\mathrm{kg})$ & $0.89 \pm 0.03$ & $0.90 \pm 0.03$ & $0.90 \pm 0.02$ & 0.814 \\
Body weight gain $(\mathrm{kg})$ & $151.6 \pm 3.5$ & $130.4 \pm 3.2$ & $139.9 \pm 2.1$ & 0.0001 \\
\hline \multicolumn{4}{l}{ 1 had initial B.W between 225 and 249 kg, G2 had initial B.W between 250 and 275 kg }
\end{tabular}

\section{Effect of initial body weight on growth and economical traits}

Results in table (1) indicate that, however G2 reached the final body weight in shorter $(\mathrm{P}<0.0001)$ period $(18 \%$ less $)$ compared to $\mathrm{G} 1$, there was no difference between the two groups concerning ADG and feed efficiency. The increase $(\mathrm{P}<0.0001)$ of $\mathrm{BW}$ gain in $\mathrm{G} 1$ relative to $\mathrm{G} 2(+16.3 \%)$ is attributed to its longer fattening period.

However, fattening period was less $(\mathrm{P}<0.0001)$ in $\mathrm{G} 2$ than in $\mathrm{G} 1$ by about 27 days (Table 1), in addition lower feeding $(\mathrm{P}<0.0001)$, and labor $(\mathrm{P}<0.0001)$ costs, there was no significant difference between the two groups in the total cost, total income and all economical traits (Table 2). It is worth to note that purchasing price of G2 (+ L.E 292) compensates the increase of feeding cost of G1.

Under the experimental circumstances, feeding costs represented about $93 \%$ of the running cost, while labor and veterinary care were 4.9 and $2.1 \%$, respectively.

\section{Experiment II}

$\mathrm{C} 2$ had longer $(\mathrm{P}<0.0001)$ fattening period $(45 \%)$ and heavier $(\mathrm{P}<0.0001)$ marketing body weight $(6.3 \%)$ compared to $\mathrm{C} 1$. On the contrary, ADG was less $(\mathrm{P}<0.0007)$ in $\mathrm{C} 2$ relative to $\mathrm{C} 1$ by $16 \%$ (Table 3 and figure 2 ). Increasing marketing $\mathrm{BW}$ from 392 in $\mathrm{C} 1$ to $417 \mathrm{~kg}$ in $\mathrm{C} 2$ had extremely negative impact on economic traits of $\mathrm{C} 2$.

Running costs were higher in $\mathrm{C} 2$ than $\mathrm{C} 1$ (Table 3), which resulted in an increase in total variable costs by $12.9 \%$ relative to $\mathrm{C} 1$ (Figure 2). Outputs of $\mathrm{C} 2$ was higher $(\mathrm{P}<0.0001)$ than $\mathrm{C} 1$ by $17.5 \%$, however gross margin $(\mathrm{P}<0.007)$, benefit/cost ratio $(\mathrm{P}<0.005)$ and net benefit/ fattening cycle were less in $\mathrm{C} 2$ than $\mathrm{C} 1$ by $51,5.4$ and $53.3 \%$, respectively (Figure 2 ).

Fattening period of $\mathrm{C} 2$ reduces the expected number of fattening cycles / year compared to $\mathrm{C} 1$ (Table 3 ). This consequently reduces the annual net return per total variable cost by about $17 \%$ (26.5 vs. $9.6 \%$ for $\mathrm{C} 1$ and $\mathrm{C} 2$, respectively).

\section{DISCUSSION}

Slow growth pattern during the $1^{\text {st }}$ phase of growth curve is most probably attributed to the physiological reaction of the calves to new managerial practice (micro-environment and management system) compared to that applied at small farm level. Changing growth curve during the $2^{\text {nd }}$ phase is referred to the compensation of growth of calves after adaptation to the new managerial practices. Decreasing ADG 
during the $3^{\text {rd }}$ phase agrees with the finding of Omar et al. (1993), and could be explained by reaching calves to sexual maturity stage (Payne and Wilson, 1999).

Table 2. Economic traits (per head) (LSM \pm S.E) of Baladi calves as affected by initial body weight (kg), (Experiment I)

\begin{tabular}{|c|c|c|c|c|}
\hline Traits & G1 & G2 & Overall mean & P value \\
\hline Number & 18 & 22 & 40 & \\
\hline \multicolumn{5}{|l|}{ Input (L.E) } \\
\hline Calf & $3488.3 \pm 21.5$ & $3780.7 \pm 19.5$ & $3649.2 \pm 14.4$ & 0.0001 \\
\hline Feeding & $1305.0 \pm 34.3$ & $1089.8 \pm 31.0$ & $1186.7 \pm 23.0$ & 0.0001 \\
\hline Labor & $68.6 \pm 1.44$ & $57.8 \pm 1.30$ & $62.7 \pm 0.97$ & 0.0001 \\
\hline Veterinary & 25 & 25 & 25 & 0.0 \\
\hline Total variable cost & $4886.7 \pm 39.2$ & $4953.2 \pm 35.4$ & $4923.3 \pm 26.3$ & 0.126 \\
\hline \multicolumn{5}{|l|}{ Outputs (L.E.) } \\
\hline Manure & $70.5 \pm 1.5$ & $59.4 \pm 1.4$ & $64.4 \pm 0.99$ & 0.0001 \\
\hline Calf's selling price & $5392.4 \pm 38.6$ & $5377.6 \pm 34.9$ & $5384.3 \pm 25.9$ & 0.811 \\
\hline Total outputs & $5462.9 \pm 40.8$ & $5436.9 \pm 36.9$ & $5448.7 \pm 27.5$ & 0.22 \\
\hline \multicolumn{5}{|l|}{ Economic traits } \\
\hline Gross margin (L.E) & $576.1 \pm 38.9$ & $483.7 \pm 35.2$ & $525.3 \pm 26.1$ & 0.200 \\
\hline Benefit/ cost ratio & $1.12 \pm 0.009$ & $1.10 \pm 0.008$ & $1.11 \pm 0.008$ & 0.161 \\
\hline \multicolumn{5}{|c|}{ Expected annual return* } \\
\hline Fattening cycles/yr $* *$ & 2.1 & 2.5 & 2.3 & \\
\hline Return / cycle $(\%)$ & $11.8 \pm 0.009$ & $9.8 \pm 0.008$ & $10.7 \pm 0.008$ & 0.179 \\
\hline Return / year $(\%)^{* * *}$ & 24.8 & 24.5 & 24.8 & \\
\hline
\end{tabular}

ADG (900 g, Table 1) obtained in the present study is less than that reported by Sadek et al. (1993), El-Bedawy et al. (1996 \& 2004) and Alsheikh et al. (2004) (1024 - $1228 \mathrm{~g}$ ), and higher than that reported by Askar and Ragab (1958); Kamar et al. (1961) and Omar et al. (1993) (600 -747 g). Meanwhile, the present result is in accordance with that reported by Galal et al. (1973) (881.0 g). Differences in age, management practices and season of growth may be the main reasons of variation in recorded ADG among the previous studies.

The non-significant difference in growth traits of G1 and G2 is most probably attributed to the narrow difference in the initial body weight (about $20 \mathrm{~kg}$, Table 1) and equal marketing body weight. The non-significant difference between G1 and G2 concerning the studied economic traits, is due to the no difference between intput and outputs.

Benefit / cost ratio and annual net return of G1 and G2 (Table 2) indicated that initial body weight of $225-275 \mathrm{~kg}$ with fattening period of $5-6$ months had no effect on the profitability of feedlot.

Decreasing ADG with age progress (in experiment II) is due to reaching calves of $\mathrm{C} 2$ the sexual maturity after which animals need more energy to gain $1 \mathrm{~kg}$ live body weight (Lawrence and Fowler, 1998). This biological phenomenon is previously recorded as a result of turning physiological activity towards fat deposition (Lawrence, and Fowler, 1998). 
Increasing feeding cost of $\mathrm{C} 2$ (due to the lower ADG) is the main factor that reduces the benefit / cost ratio, and gross margin. The obtained net return / fattening cycle in G1 $(11.8 \%$, Table 2$)$ or in $\mathrm{C} 1(10.7 \%$, table 3$)$ is close to that reported by Alsheikh et al. (2004, $12 \%$ ) under commercial farm condition. The drastic decrease in number of expected fattening cycles and annual net return / year of C2 (Table 3) draw the attention to that increasing marketing body over $400 \mathrm{~kg}$ minimizes feedlot profitability. This trend is close to that reported by El-Asheeri et al. (2008).

In conclusion initial body weight (between 225 and $275 \mathrm{~kg}$ ) and marketing body weight around $400 \mathrm{~kg}$ are the better to maximize feedlot return under Egyptian conditions.

Table 3. Growth performance and economic traits (LSM \pm S.E) of Baladi calves as affected by marketing body weight (Experiment 2 )

\begin{tabular}{|c|c|c|c|}
\hline Traits & C1 & C2 & P Value \\
\hline Number of calves & 22 & 18 & \\
\hline \multicolumn{4}{|l|}{ Growth characteristics } \\
\hline Fattening period (day) & $151.1 \pm 5.4$ & $219.2 \pm 6.0$ & 0.0001 \\
\hline Marketing body weight (kg) & $392.6 \pm 2.2$ & $417.4 \pm 2.5$ & 0.0001 \\
\hline Average daily gain $(\mathrm{kg})$ & $0.93 \pm 0.03$ & $0.78 \pm 0.03$ & 0.0007 \\
\hline \multicolumn{4}{|l|}{ Economical characteristics } \\
\hline Calves & $3674.7 \pm 38.2$ & $3617.8 \pm 42.3$ & 0.32 \\
\hline Feeding & $1178.0 \pm 50.9$ & $1841.7 \pm 56.3$ & 0.0001 \\
\hline Labor & $60.5 \pm 2.2$ & $87.7 \pm 2.4$ & 0.0001 \\
\hline Veterinary care & $25.0 \pm 0.6$ & $32.6 \pm 0.6$ & 0.0001 \\
\hline Total variable cost (L.E) & $4937.9 \pm 58.8$ & $5577.0 \pm 65.1$ & 0.0001 \\
\hline \multicolumn{4}{|l|}{ Outputs (L.E) } \\
\hline Manure & $62.1 \pm 2.2$ & $90.1 \pm 2.5$ & 0.0001 \\
\hline Calf's selling price & $5397.6 \pm 31.4$ & $5740.0 \pm 34.7$ & 0.0001 \\
\hline Total Outputs (LE) & $5459.7 \pm 31.4$ & $5830.0 \pm 34.7$ & 0.0001 \\
\hline \multicolumn{4}{|l|}{ Economic traits } \\
\hline Gross margin (L.E) & $521.8 \pm 63.1$ & $252.9 \pm 69.7$ & 0.007 \\
\hline Benefit / cost ratio & $1.11 \pm 0.01$ & $1.05 \pm 0.01$ & 0.005 \\
\hline \multicolumn{4}{|l|}{ Expected annual return* } \\
\hline Number of fattening cycles/ year** & 2.4 & 1.7 & \\
\hline Net return / cycle $(\%)^{*}$ & $10.7 \pm 1.3$ & $4.95 \pm 1.4$ & 0.004 \\
\hline Net return / year $(\%) * * *$ & $26.5 \pm 2.8$ & $9.6 \pm 3.1$ & 0.0003 \\
\hline
\end{tabular}

C1: Claves that allowed to grow up to $400 \mathrm{~kg}$

$\mathrm{C} 2$ : Claves that allowed to grow between 415 and $425 \mathrm{~kg}$

* Calculated based on the total variable cost

** Calculated as 365 day divided by fattening period.

*** Calculated as the number of expected fattening cycle / year multiplied by net return / cycle 


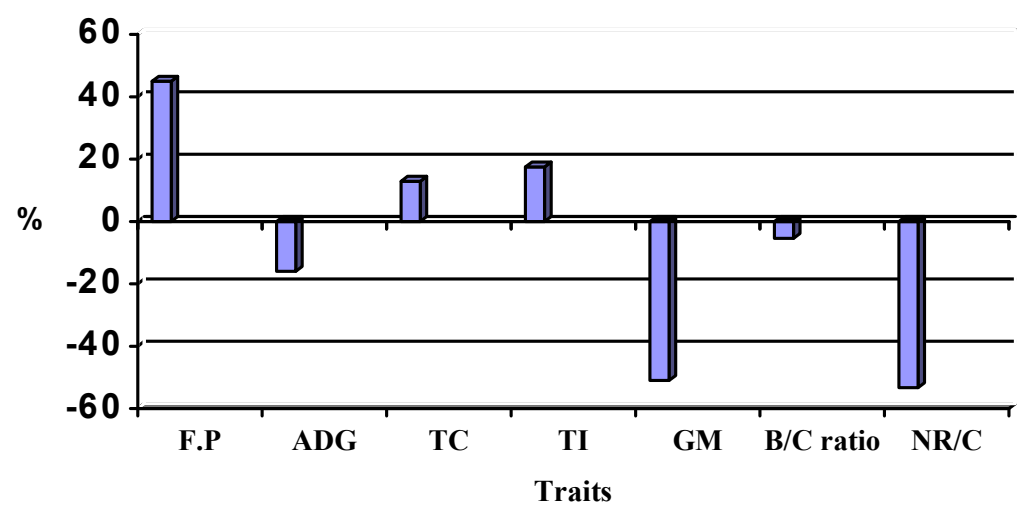

Figure 2. Change (\%) in growth (fattening period, FP and ADG) and economic $(T C=$ total cost; $T I$, total income, $G M=$ gross margin, $B / C$ ratio $=$ benefit $/$ cost ratio and net return / cycle) of $\mathrm{C} 2$ relative to $\mathrm{C} 1$

\section{ACKNOWLEDGEMENT}

The author would like to thank Dr. M. A. M. Ibrahim, Associate Professor, Animal Husbandry, Faculty of Agriculture, Cairo University for his sincere help in analyzing data. Gratitude is also extended to the experimental station of Faculty of Agriculture, Cairo University for offering the animals and the running cost of this experiment.

\section{REFERENCES}

Alsheikh, S. M., A. A. Younis, M. M. Mokhtar, 2004. Biological and economic assessment of fattening Egyptian native Baladi male calves in a newly reclaimed area. Egyptian J. Anim. Prod., 41, Suppl. Issue, Nov.: 85- 91.

Ashour G, A. S. El-Naggar, M.M. Youssef and H.M. Mourad, 2000. Growth performance and metabolic profile of Egyptian cattle and Buffalo calves. Proceedings of $3^{\text {rd }}$ Africa conference of animal agriculture and $11^{\text {th }}$ Conference of Egyptian Society of Animal Production, Alexandria, Egypt, 6-9 November: 469477.

Asker, A. A. and M. T. Ragab, 1959. Fattening Egyptian steers in Tahreer province. Alex. J. Agric. Research, 7: 157-

El-Asheeri, Amal, K. A. S. Sami and M. A. Radwan. 2008. Biological performance and economic indicators of fattened Baladi bullocks under two fattening systems. Egyptian J. Animal Production, 45, suppl. Issue, 69-77.

El- Bedawy, T. M., M. A. I. Salem and E. A. Badr, 1996. Effect of dietary fat on growth performance and carcass characteristics of finishing bulls. Egyptian Journal of Animal Production, 33(Supplement issue): 103-111. 
El- Bedawy, T. M., M. A. I. Salem and A. S. Sami, 2004. Calcium soaps in low or high roughage rations: 2- Effect on growth performance, carcass characteristics and meat quality of growing finishing Baladi bulls. Egyptian J. Anim. Prod., 41(2): 61-71.

Galal, E., A. A. Younis, K. G. Attia and A. B. Awad, 1973. The performance of Egyptian native Baladi male calves during fattening. Egyptian J. Anim. Prod., 2: 71.

Kamar, G. A. R., A. L. Badreldin and H. Z. Abd El-Hady, 1961. Factors affecting gain in fattening Egyptian steers on clover. J. Anim. Prod., U. A. R., 19: 32.

Lawrence, T. L. H. and V. R. Fowler, 1998. Growth of Farm Animals. $2^{\text {nd }}$ edition, Chapter 6, CAB International, UK.

Ministry of Agriculture and Land Reclamation, 2006. Census of animal wealth, Economics affair sector.

Morsy, M. A., A. A. Nigm, A. Mostageer and F. Pirchner, 1984. Some economic characteristics of the Egyptian Baladi cattle. Egyptian J. Anim. Prod. 42, 1-2: 273-285.

Nigm A. A., A. Mostageer, M. A. Morsy, M. A. I. Salem and F. Pirchner, 1984. Feed efficiency of beef production of Baladi and its crossbreds with central European cattle. Z. Tierzuchtg. Zuchtgsbiol. 101: 173-181.

NRC, 1996. Nutrient Requirements of beef cattle. National Research Council, National Academy Press, Washington, D. C. Seventh Revised Edition: Update 2000. http://www.nap.edu/catalog/9791.html

Omar, S.S., M.A. Houria and G. A. Baraghite, 1993. Studies on growth performance of male buffalo and bovine calves under commercial fattening farms in Menofiya province. Egyptian J. Anim. Prod., 30 (2):117-128.

Payne, W.J.A. and R. T. Wilson, 1999. An Introduction to Animal Husbandry in The Tropics. $5^{\text {th }}$ edition, Chapter 19, Blackwell Science Ltd, UK

Sadek, R. R., M. A. Morsy, A. A. Nigm, M. A. M. Ibrahim and A. M. Sabry, 1993. The effect of grading up Baladi cattle with Friesian on meat production performance. Egyptian J. Anim. Prod., 30 (2): 143-160.

SAS (2001) SAS institute Inc., Cary, NC. USA. 


\section{أربحية تسمين العجول البلاية تحت نظم تسمين مختلفة}

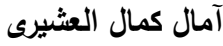

\section{قسم الإنتاج الحيوانس- كلية الزراعة- جامعة القاهرة- الجيزة- مصر}

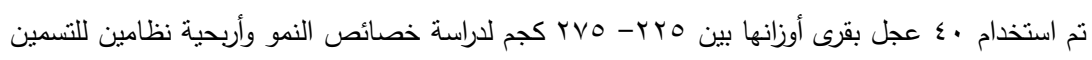

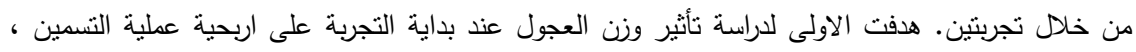

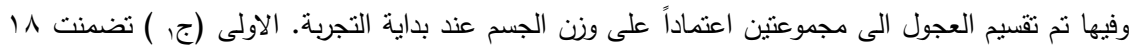

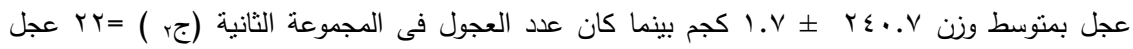

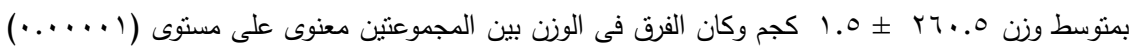

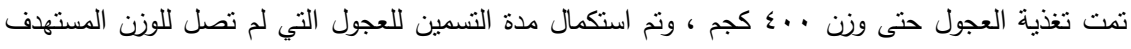

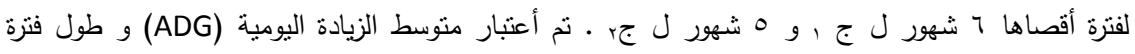
التسمين ك مقاييس للنمو بينما صفات قيمة العائد/ التكاليف، و

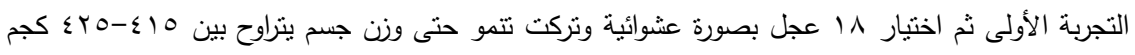

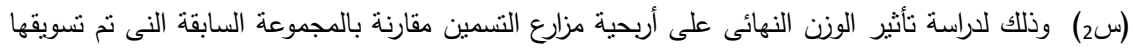

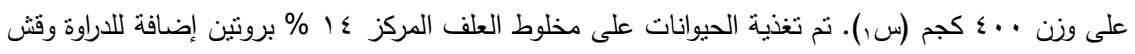

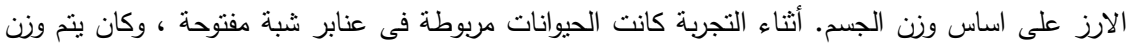

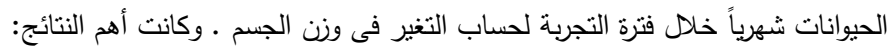

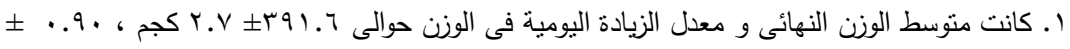

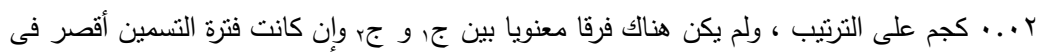

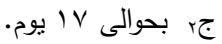

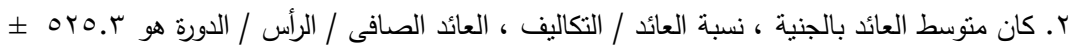

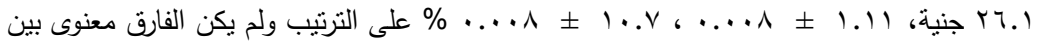

r. أثشارت نتائج الجزء الثانى من التجربة أن زيادة وزن النسويق عن .ـ كجم كان له نأثير سلبى

$$
\text { على مظاهر النمو وأربحية المزرعة. }
$$

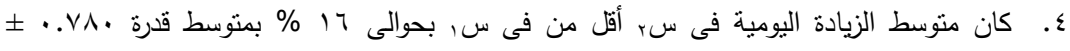

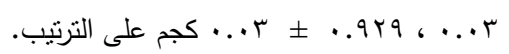

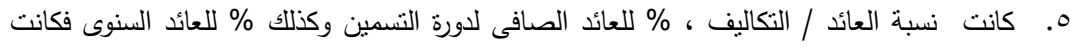

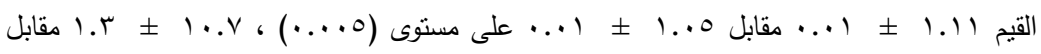

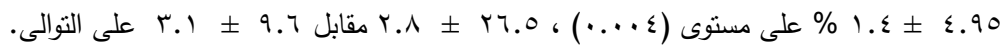




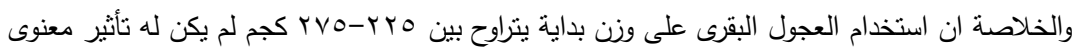

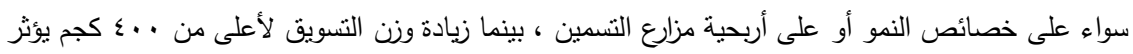

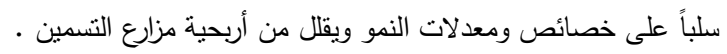

